\begin{tabular}{|l|l|}
\hline JURNAL ABDI MASYA & Volume 1 No 2 \\
E-ISSN : 2774-2849 & Mei 2021 \\
P-ISSN : 2774-12-124 & Website : https://jurnal.sttw.ac.id/index.php/abma/about \\
\hline
\end{tabular}

\title{
PEMBERDAYAAN UKM PENGRAJIN RUMAH TANGGA GUNA MENINGKATKAN PRODUKTIVITAS MELALUI TEKNOLOGI TEPAT GUNA KABUPATEN BOYOLALI JAWA TENGAH
}

\section{THE EMPOWERMENT OF THE SMALL HOME INDUSTRY OF HOUSEHOLD CRAFTSMEN TO INCREASE THE PRODUCTIVITY THROUGH THE APPROPRIATE TECHNOLOGY PROGRAM IN BOYOLALI CENTER JAVA}

\author{
Abdul Jalil ${ }^{1^{*}}$, Siswanto ${ }^{2 *}$, Erniyawati Mustaqomah ${ }^{3^{*}}$ \\ ${ }_{1}^{1}$ Program Studi Sekretari, Politeknik Pratama Mulia, Surakarta \\ ${ }^{2}$ Program Studi Teknologi Mesin, Politeknik Pratama Mulia, Surakarta \\ ${ }^{3}$ Program Studi Akuntansi, Politeknik Pratama Mulia, Surakarta \\ *Emai: abduljalil170773@gmail.com
}

\begin{abstract}
ABSTRAK
Pemberdayaan industri kecil dan rumah tangga merupakan kebijakan pemerintah yang berbasis ekonomi kerakyatan. Hal ini merupakan suatu bentuk kepercayaan kepada kemandirian masyarakat dalam melakukan kegiatan ekonominya. Pada kenyataanya industri kecil dan rumah tangga merupakan industri yang tahan banting terhadap keadaan ekonomi yang tidak menentu seperti saat ini. Dukuh Dawar Desa Manggis Kecamatan Mojosongo Kabupaten Boyolali, Jawa Tengah. Di desa tersebut masyarakatnya sebagian besar berwira usaha kerajinan rumah tangga. Usaha berjenis home industry ini telah lama ditekuni oleh masyarakat di desa itu. Pekerjaan kreatif ini sudah menjadi salah satu simbol desa tersebut dan ikut membesarkan nama Boyolali sebagai salah satu kabupaten penghasil kerajinan rumah tangga di Jawa Tengah. Produk dari usaha rumah tangga tersebut banyak macamnya dan bervariasi. Kerajinan rumah tangga termasuk usaha yang sudah berkembang sejak lama dan kini semakin ramai dan menunjukkan kemajuan yang sangat pesat. Permasalahan yang dihadapi oleh UKM saat ini adalah mesin yang digunakan untuk membuat kerajinan rumah tangga sangat sederhana, sehingga jumlah produksinya terbatas, padahal pemesanan kerajinan rumah tangga tersebut tiap bulannya meningkat pesanan datang dari luar daerah dan luar pulau.

Program Penerapan Teknologi Tepat Guna bagi masyarakat dari Kementrian Riset dan Teknologi Badan Riset dan Inovasi Nasional ini membantu mengatasi permasalahan yang ada di UKM tersebut dengan mendanai pembuatan mesin serta pelatihan-pelatihannya. Diharapkan dengan program TTG ini para pengrajin rumah tangga dapat menularkan maupun membina masyarakat sekitarnya, sehingga masyarakat disekitarnya mempunyai motivasi untuk berwirausaha baru dan dapat menambah wawasan sehingga dapat mengurangi urbanisasi bagi generasi mudanya.Terlaksananya program TTG kepada Masyarakat ini secara khusus meningkatkan ketrampilan yang mendukung produktifitas serta dapat meningkatkan pendapatan para pengrajin rumah tangga dan kelompoknya di Kampung Dawar Desa manggis Kecamatan Mojosongo Kabupaten Boyolali. Dan diharapkan dengan program ini dalam skala Nasional akan meningkatkan pendapatan perkapita daerah.
\end{abstract}

Kata kunci : Pengrajin rumah tangga, mesin teknologi tepat guna, kualitas, Produktifitas, peningkatan pendapatan

\section{ABSTRACT}

The empowerment of the small home-industry is a government policy on the people-base economy. This policy is a trust on the independence of people in performing the economy activity; it is real that the small home-industry is tenacious or resilient toward the situation of unstable economy at present. The people living in Dawar village, Manggis sub-district, Mojosongo district, Boyolali Regency, Central Java Province, most of them, make household crafts. The villagers have been developing the small home-industry business since a long time ago, they have performed it in heredity. This small home-industry has become one of the symbols of the village and has helped to raise the name of Boyolali as the one of regencies in Central Java producing the household crafts. 
The household crafts have many types and variation, the business of household crafts develops rapidly at preset and its progress is very rapid. The problem happened this time is that the machines used to produce the household crafts are very simple. Consequently, the number of production is limited whereas the order of the household crafts increases every month, either from inside Java or outside Java.

Ministry of Research and Technology/National Research and Innovation Bureau, by the program of application of appropriate technology for people, has assisted the small home-industries to overcome the problem they face by funding them to make the required machine and its training. Then, the craftsmen were expected to share their knowledge and experience to other villagers and guide and motivate them in order to have own business; it can minimize the number of young people to urbanize. The accomplishment of the program of application of appropriate technology for people can improve the craftsmen's skil and increase the productivity and the income of the craftsmen and their related parties in the Dawar village. Furthermore, in national scale, this program is expected to raise the regional per capita income.

Key Words: craftsmen of household, appropriate technology machine, quality, productivity, to increase the income,

\section{Submit: 26 April 2021, Revision: 29 April 2021, Accepted: 3 Mei 2021} Published: 28 Mei 2021

\section{PENDAHULUAN}

Industri rumah tangga bukan merupakan hal yang baru di Indonesia. Pemberdayaan industri kecil dan rumah tangga merupakan kebijakan pemerintah yang berbasis ekonomi kerakyatan hal ini merupakan suatu bentuk kepercayaan kepada kemandirian masyarakat dalam melakukan kegiatan ekonominya Menurut Riyanto dkk [1], [2], [3], pada kenyataanya industri kecil dan rumah tangga merupakan industri yang tahan banting terhadap keadaan ekonomi yang tidak menentu seperti saat ini Menurut Wardani Dwi (2012) [4] Dukuh Dawar Desa Manggis Kecamatan Mojosongo Kabupaten Boyolali, Jawa Tengah. Di desa tersebut masyarakatnya sebagian besar sebagai usaha kerajinan rumah tangga seperti sapu dan lain sebagainya. Usaha berjenis Home Industri ini telah lama ditekuni oleh masyarakat di Desa itu. Walau tidak seluruh masyarakatnya menekuni pekerjaan sebagai pengrajin rumah tangga tetapi pekerjaan kreatif ini sudah menjadi salah satu simbol desa tersebut dan ikut membesarkan nama Boyolali sebagai salah satu kabupaten penghasil kerajinan rumah tangga di Jawa Tengah. Produk dari rumah tangga tersebut banyak macamnya dan bervariasai. Kerajinan rumah tangga termasuk usaha yang sudah berkembang sejak lama dan kini semakin ramai dan menunjukkan kemajuan yang sangat pesat [5]. Di dukuh Dawar Desa Manggis tersebut yang mengembangkan kerajinan rumah tangga diantaranya adalah Bapak Muhammad Farouq (37 th) dan Bapak Mahfud Anshori (32 th) dengan papan nama pengrajin Rumah tangga "Krida Mukti" dan "Makaryo" dengan alamat dukuh Dawar Desa Manggis Kecamatan Mojosongo Kabupaten Boyolali Jawa Tengah.

Permasalahan yang dihadapi pada UKM saat ini adalah mesin yang digunakan untuk membuat kerajinan rumah tangga yang berupa mesin dowel, mesin gergaji dan mesin bor yang digunakan sangat sederhana dan secara manual, sehingga jumlah produksinya terbatas padahal pemesanan kerajinan rumah tangga tersebut tiap bulannya meningkat pesanan datang dari luar daerah dan luar pulau.

Penjualan kerajinan rumah tangga ini sementara hanya melayani pasar lokal dan luar provinsi jawa tengah, sementara ini yang banyak memesan kerajinan dari luar jawa adalah, Kalimantan. Sulawesi dan Sumatra

(Sumber : Survey Dukuh Dawar Desa Manggis Kecamatan Mojosongo Kabupaten Boyolali Jawa Tengah) 
Kedua pengrajin tersebut saat ini mau meningkatkan produksinya supaya permintaan dari luar kota dapat terpenuhi. maka dari itu kedua pengrajin memerlukan mesin teknologi tepat guna yang standar produk sehingga waktu yang dibutuhkan cepat tanpa harus mengurangi tenaga kerja,

Terlaksananya program ini secara khusus akan meningkatkan ketrampilan yang mendukung produktifitas serta dapat meningkatkan pendapatan kedua UKM pengrajin rumah tangga beserta keluarganya dan masyarakat disekitarnya, diharapkan dengan program ini dalam skala Nasional akan meningkatkan pendapatan perkapita daerah. Sebenarnya Desa Manggis tersebut masih banyak terdapat industri kecil/ industri kerajinan rumah tangga serta rumah makan, Meskipun banyak potensi yang perlu dikembangkan, tetapi belum ada investasi bidang teknologi tepat guna yang telah dimanfaatkan baik bidang energi, bidang pangan, bidang pertanian, bidang konstruksi, bidang material, sehingga hal ini menjadi bahan pertimbangan lokasi pengrajin rekanan yang diajukan dalam Program Penerapan Tekonologi Tepat Guna Kepada Masyarakat Kementrian Riset dan Teknologi /Badan Riset dan Inovasi Nasional

\section{METODE PELAKSANAAN}

Pelaksanaan Program Penerapan Teknologi Tepat Guna kepada Masyarakat diawali dengan sosialisasi program dilapangan serta pemetaan permasalahan yang ada di kedua pengarjin rumah tangga di Dukuh Dawar Desa Manggis Kecamatan Mojosongo Kabupaten Boyolali, Hasil diskusi dan pemetaan permasalahan yang ada di kedua pengrajin tersebut dijadikan permasalahan yang harus segera dilakukan diantaranya sebagai berikut :

Pembuatan mesin Dowel dan Mesin gergaji multiguna serta mesin bor di lakukan di laboratorium Teknik mesin Politeknik Pratama Mulia Surakarta

Ketiga mesin tersebut sekarang sudah digunakan untuk menproduksi kerajinan rumah tangga, tinggal waktu untuk menuju sukses dengan keberhasilan peningkatan produksi kerajinan rumah tangga tersebut.

Kegiatan pelatihan Finishing produk kerajinan rumah tangga sudah dilakukan tinggal team Program Penerapan Teknologi Tepat Guna kepada Masyarakat memonitor dan kunjungan ke lokasi setiap 2 minggu sekali untuk memonitor kegiatan tersebut dapat dilaksanakan atau belum di kedua mitra tersebut dan masih perlunya pembimbingan maupun pendampingan sampai nantinya kedua mitra dapat berjalan dengan sendirinya dengan baik Pelatihan manajemen dan administrasi, pembukuan sederhana dan manajemen pemasaran sudah dilakukan secara bertahap mengingat masih dalam situasi pandemik covid 19 juga sama masih dilakukan monitoring dari team Program Penerapan Teknologi Tepat Guna kepada Masyarakat setiap 2 minggu sekali karena letak kampus dan kedua mitra jaraknya tidak begitu jauh diharapkan kedua mitra tersebut dapat berkembang sesuai yang diinginkan dan nantinya dapat membimbing dan membina UKM-UKM yang ada disekitarnya

\section{HASIL DAN DISKUSI}

Program Penerapan Teknologi Tepat Guna kepada Masyarakat ini akan menghasilkan Penerapan Mesin Teknologi Tepat Guna pada kedua UKM sesuai fungsinya sehingga akan meningkatkan produksi kerajinan rumah tangga serta Peningkatan pengelolaan manajemen di kedua UKM dan tertibnya administrasi keuangan dan pembuatan laporan keuangan sederhana setiap harinya, dengan adanya Penerapan Teknologi Tepat Guna kepada Masyarakat ini akan meningkatkan produksi kerajinan rumah tangga sehingga nantinya dapat meningkatkan pendapatan bagi pengrajin dan keluarganya serta sebagai wacana bagi industri kecil lainya, bahwa mesin ini dapat digunakan untuk pertukangan, pengrajinpengrajin yang berbahan dasar dari kayu

Mesin ini dalam proses pemakaiannya sangat mudah, sederhana dengan tingkat keselamatan kerja yang terjamin dan perawatannya tidak terlalu sulit. 
Tabel 1. Spesifikasi Mesin Dowel yang di rekayasa

\begin{tabular}{lll} 
Daya mesin & $:$ & $3 \mathrm{PK}$ dan $1.5 \mathrm{PK}$ \\
Putaran mesin & $:$ & $1450 \mathrm{rpm}$ dan $1420 \mathrm{rpm}$ \\
Kapasitas mesin & $:$ & 7 Batang tangkai sapu / 1 Menit \\
Lebar mesin & $:$ & $600 \mathrm{~mm}$ \\
Panjang mesin & $:$ & $800 \mathrm{~mm}$ \\
Tinggi & $:$ & $\mathrm{mm}$ \\
\hline
\end{tabular}

Tabel 2. Spesifikasi Mesin Gergaji serbaguna yang di rekayasa

\begin{tabular}{llll} 
Daya mesin & $:$ & $2 \mathrm{PK}$ \\
Putaran mesin & $:$ & $1400 \mathrm{rpm}$ \\
Kapasitas mesin & $:$ & 28 Pemotongan tangkai Batang \\
& & tangkai sapu / 1 Menit & \\
Lebar mesin & $:$ & $800 \mathrm{~mm}$ \\
Panjang mesin & $:$ & $850 \mathrm{~mm}$ \\
Tinggi & $:$ & $900 \mathrm{~mm}$ \\
\hline
\end{tabular}

Tabel 3. Spesifikasi Mesin Bor yang di rekayasa

\begin{tabular}{lll}
\hline Daya mesin & $:$ & $1.5 \mathrm{PK}$ \\
Putaran mesin & $:$ & $1200 \mathrm{rpm}$ \\
Kapasitas mesin & $:$ & 40 pelubangan / 1 Menit \\
Lebar mesin & $:$ & $200 \mathrm{~mm}$ \\
Panjang mesin & $:$ & $380 \mathrm{~mm}$ \\
Tinggi & $:$ & $560 \mathrm{~mm}$ \\
\hline
\end{tabular}

\section{Perbandingan Ekonomis}

Tabel. 4 Perbandingan Pemakaian Mesin Dowel yang Ada di UKM dan Mesin yang dibuat

\begin{tabular}{llcc}
\hline \multirow{3}{*}{ No } & Jenis Kegiatan & \multicolumn{2}{c}{ Proses pengolahan } \\
\cline { 3 - 4 } & & Mesin di UKM & $\begin{array}{c}\text { Mesin yang } \\
\text { Direkayasa }\end{array}$ \\
\hline 1 & Proses Penggergajian & Satu Pisau & Dua Pisau \\
2 & Waktu Produksi & 3 Batang / Menit & 7 Batang/ Menit \\
3 & Daya & 1,5 PK dan 1 PK & 3 PK dan 1.5 PK \\
4 & Hasil Pengerjaan & $70 \%$ kehalusan & $95 \%$ kehalusan \\
5 & Biaya yang ditanggung & $100.000 /$ bulan & $60.000 /$ bulan \\
6 & Perawatan & Rumit & Mudah \\
\hline
\end{tabular}

Dari tabel 4 di atas didapat perbandingan ekonomis mesin dowel yang ada di UKM dan mesin dowel yang direkayasa dalam produksi kerajinan rumah tangga mengalami peningkatan produksi sebesar $130 \%$, dengan ketentuan pisau yang digunakan 2 buah tingkat kehalusan dalam finishing meningkat $25 \%$ sedangkan biaya operasional mengalami penurunan sebesar $40 \%$, tetapi ada peningkatan dalam penggunaan daya motor listrik dari 1,5 Pk menjadi $3 \mathrm{Pk}$ untuk penggerak utamanya 


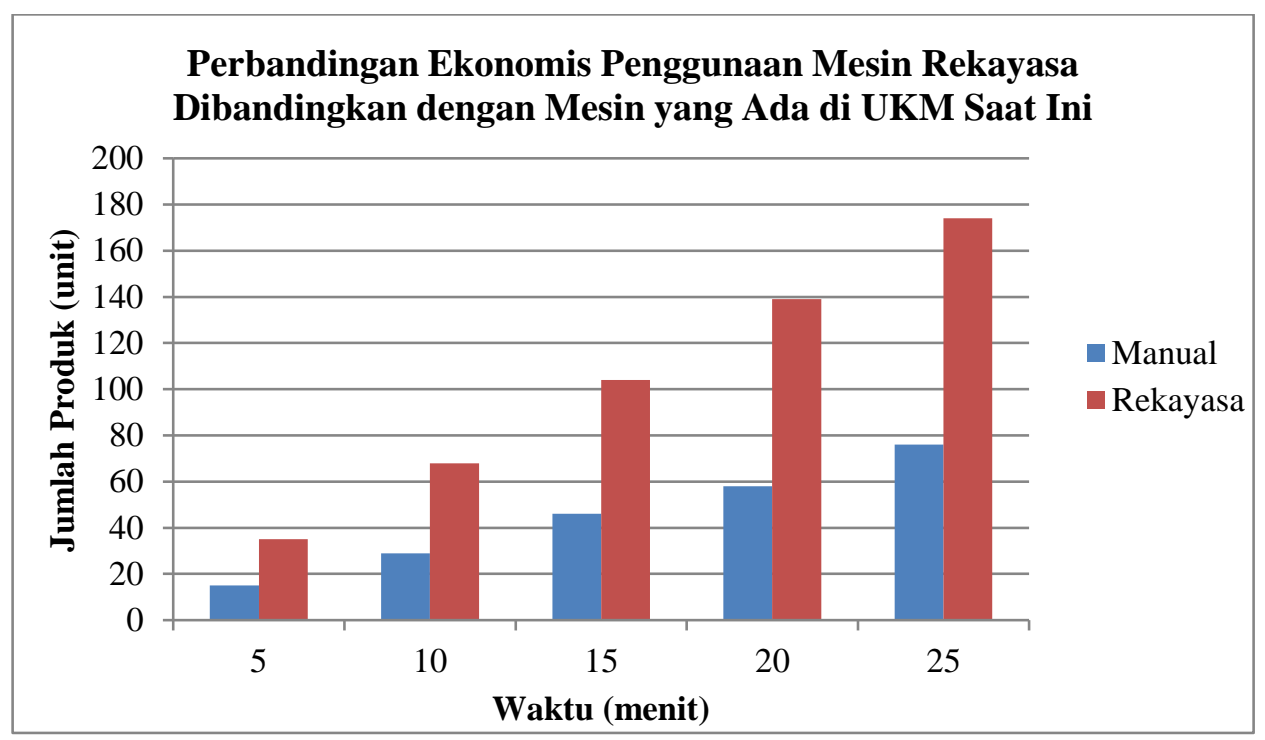

Gambar 1. Grafik perbandingan hasil pengerjaan mesin yang direkayasa dengan mesin yang ada di UKM saat ini

Dari grafik 1 Grafik perbandingan hasil pengerjaan mesin dowel yang direkayasa dengan mesin dowel yang ada di UKM saat ini didapat peningkatan produksi dari waktu pelaksanaan ada peningkatan produksi sebesar $130 \%$ dari waktu yang sama, sehingga mesin yang telah diberikan pada UMKM saat ini sudah digunakan produksi setiap harinya.

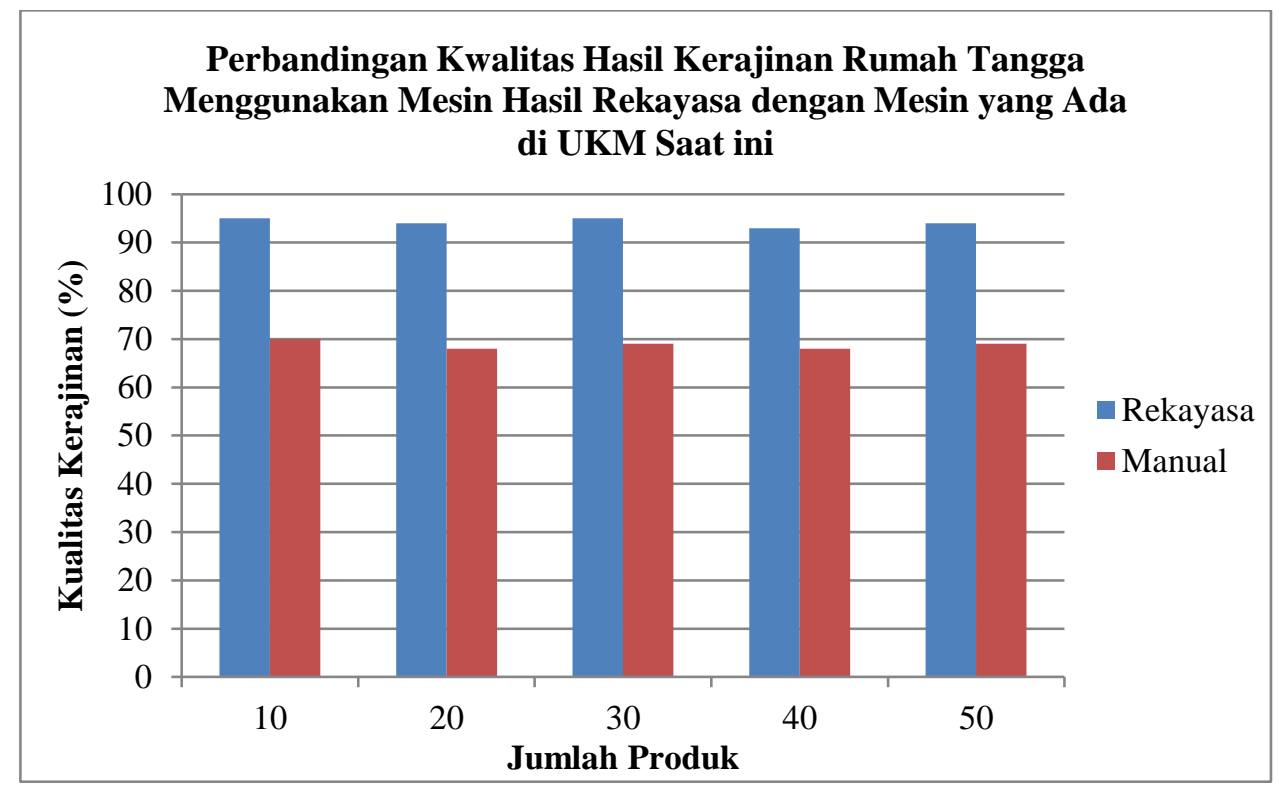

Gambar 2. Grafik Perbandingan Kwalitas Kerajinan dengan Mesin Hasil Rekayasa

Grafik 2 yang menunjukkan perbandingan kwalitas pengerjaan terutama kehalusan kayu dalam finishing dari hasil pengerjaan mesin dowel yang direkayasa dengan mesin dowel yang ada di UKM saat ini didapat peningkatan kualitas sebesar dari waktu pelaksanaan sebesar $60 \%$ dari waktu yang sama, sehingga mesin yang telah diberikan pada UMKM saat ini layak untuk produksi setiap harinya. 


\section{Perbandingan Ekonomis}

Tabel. 5 Perbandingan Pemakaian Mesin Gergaji yang Ada di UKM dan Mesin yang Direkayasa

\begin{tabular}{clll}
\hline \multirow{2}{*}{ No } & \multicolumn{2}{c}{ Jenis Kegiatan } & \multicolumn{2}{c}{ Proses pengolahan } \\
\cline { 3 - 4 } & Proses Penggergajian & Piringan gergaji & Mesin yang Direkayasa \\
\hline 1 & Waktu Produksi & 12 Batang / Menit & 18 Batang/ Menit \\
3 & Daya & $1 \mathrm{PK}$ & $1.5 \mathrm{PK}$ \\
4 & Hasil Pengerjaan & $75 \%$ kehalusan & $95 \%$ kehalusan \\
5 & Biaya yang ditanggung & $100.000 /$ bulan & $60.000 /$ bulan \\
6 & Perawatan & Rumit & Mudah \\
\hline
\end{tabular}

Dari tabel 5 diatas didapat perbandingan ekonomis dalam penggunaan mesin gergaji yang ada di UKM dan mesin gergaji yang direkayasa selama digunakan produksi setiap harinya mengalami peningkatan produksi sebesar $50 \%$ pisau yang digunakan jenis baja yang berbeda dan tingkat kehalusan dalam finishing meningkat $20 \%$ sedangkan biaya operasional mengalami penurunan sebesar $40 \%$, tetapi ada peningkatan daya motor listrik dari $1 \mathrm{PK}$ menjadi 1,5 PK untuk penggerak utamanya

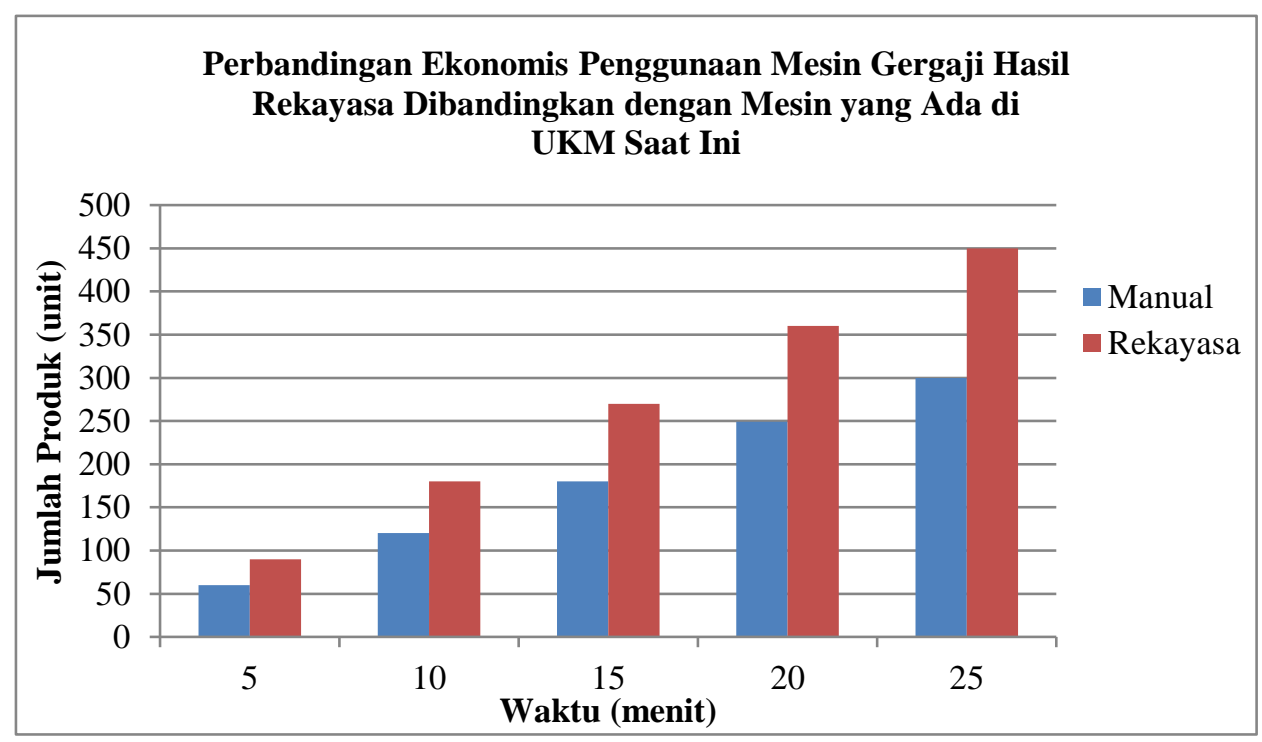

Gambar 3. Grafik Perbandingan Hasil Pengerjaan Mesin Gergaji yang Direkayasa dengan Mesin yang Ada di UKM Saat Ini

Grafik 3 menunjukan perbandingan hasil pengerjaan mesin gergaji yang direkayasa dengan mesin gergaji yang ada di UKM saat ini didapat peningkatan produksi dari waktu pelaksanaan ada peningkatan produksi sebesar $30 \%$ dari waktu yang sama, sehingga mesin gergaji yang telah diberikan pada UKM saat ini sudah digunakan untuk produksi setiap harinya. 


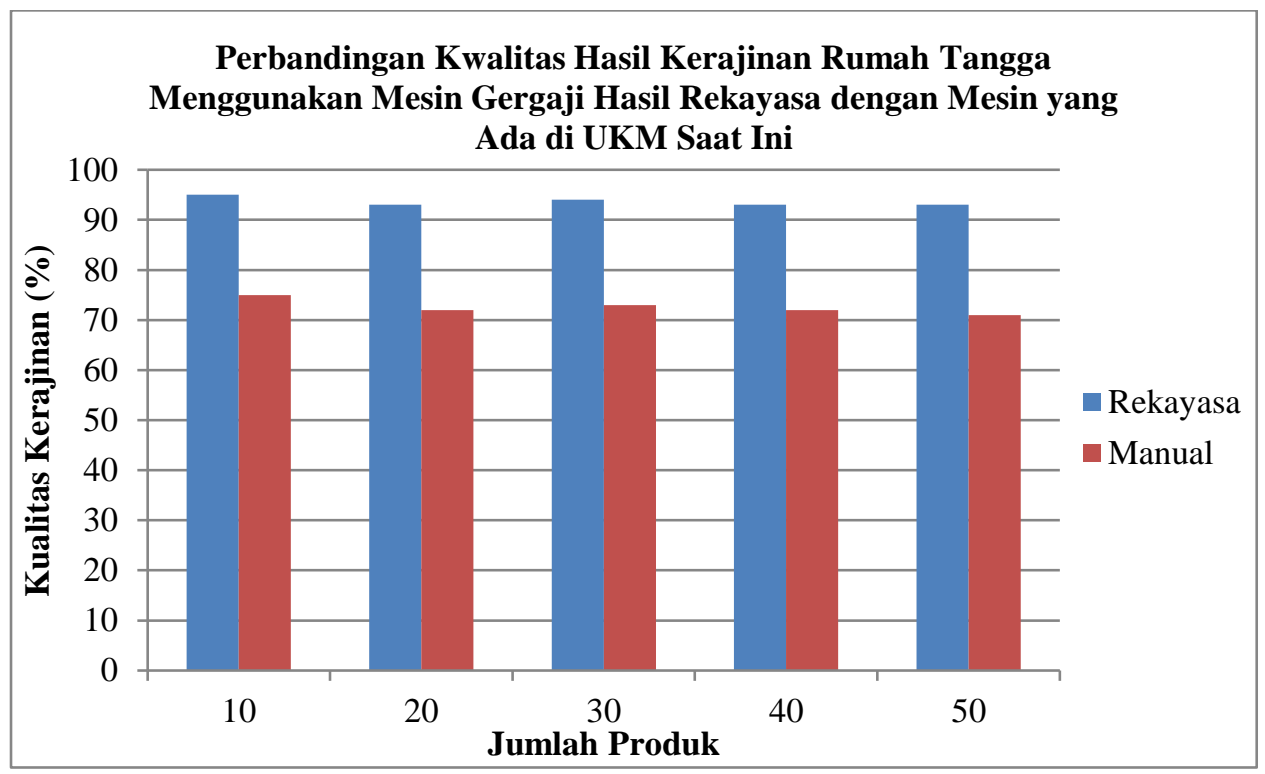

Gambar 4. Grafik Perbandingan Kwalitas Kerajinan dengan Mesin Gergaji Hasil Rekayasa dengan Mesin yang Ada di UKM Saat Ini

Grafik 4 yang menunjukkan perbandingan kwalitas pengerjaan terutama kepresisian dan tingkat kehaluan kayu dalam penggergajian mesin gergaji yang direkayasa dengan mesin gergaji yang ada di UKM saat ini didapat peningkatan kualitas sebesar $24 \%$ dari waktu pelaksanaan yang sama sehingga mesin gergaji yang telah diberikan pada UMKM saat ini dapat digunakan untuk produksi setiap harinya.

\section{Perbandingan Ekonomis}

Tabel. 6 Perbandingan Pemakaian Mesin Bor yang Ada di UKM dan Mesin yang Direkayasa

\begin{tabular}{clcc}
\hline \multirow{2}{*}{ No } & \multirow{2}{*}{ Jenis Kegiatan } & \multicolumn{2}{c}{ Proses pengolahan } \\
\cline { 2 - 4 } & Mesin di UKM & Mesin yang Direkayasa \\
\hline 1 & Proses Pengeboran & Mata bor biasa & Mata Bor Stainless steel \\
2 & Waktu Produksi & 20 lubang / Menit & 34 Lubang / Menit \\
3 & Daya & $0.5 \mathrm{PK}$ & $1 \mathrm{PK}$ \\
4 & Hasil Pengerjaan & $80 \%$ kehalusan & $95 \%$ kehalusan \\
5 & Biaya yang ditanggung & $100.000 /$ bulan & $60.000 /$ bulan \\
6 & Perawatan & Rumit & Mudah \\
\hline
\end{tabular}

Dari tabel 6 di atas didapat kesimpulan bahwa perbandingan ekonomis dalam penggunaan mesin bor yang ada di UKM dan mesin bor yang direkayasa selama digunakan produksi setiap harinya mengalami peningkatan produksi sebesar $40 \%$ mata bor yang digunakan jenis Stainless steel dan tingkat kehalusan dalam pengeboran meningkat $15 \%$ sedangkan biaya operasional mengalami penurunan sebesar $40 \%$, tetapi ada peningkatan daya motor listrik dari 0,5 PK menjadi $1 \mathrm{PK}$ untuk penggerak utamanya. 


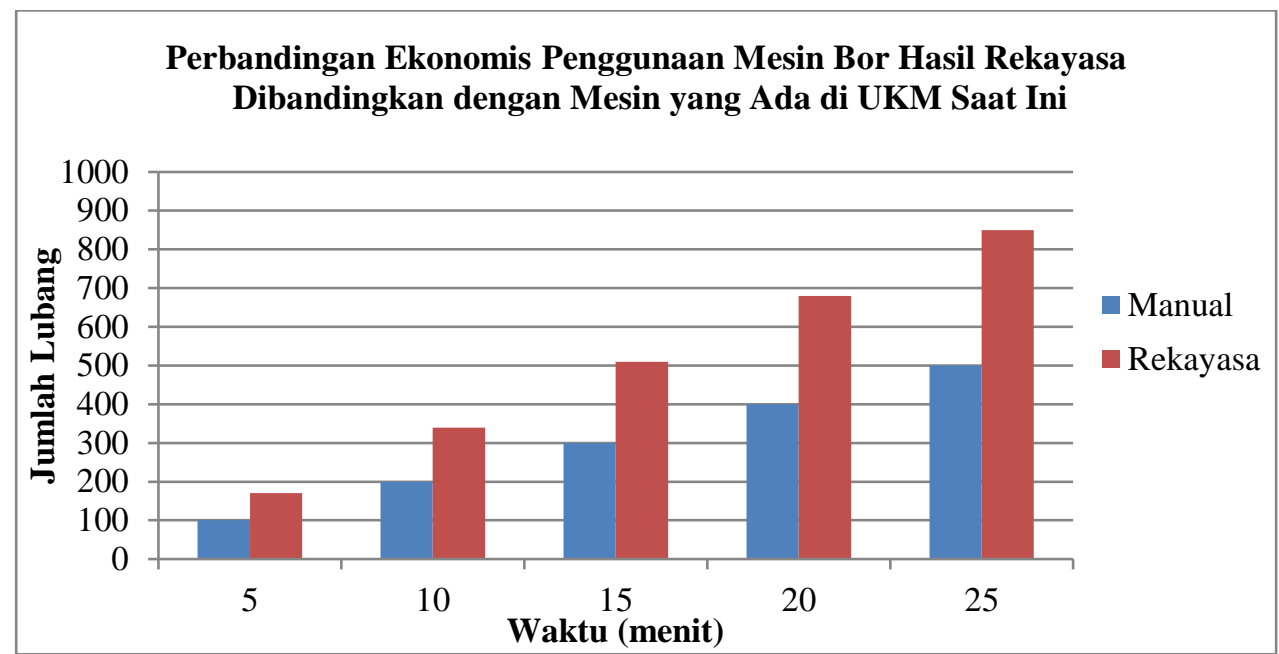

Gambar 5. Grafik Perbandingan Hasil Pengerjaan Mesin Bor yang Direkayasa dengan Mesin yang Ada di UKM Saat Ini

Grafik 5 menunjukan perbandingan hasil pengeboran mesin bor yang direkayasa dengan mesin bor yang ada di UKM saat ini didapat peningkatan produksi dari waktu pelaksanaan ada peningkatan produksi sebesar 39\% dari waktu yang sama, sehingga mesin bor yang telah diberikan pada UKM saat ini sudah digunakan untuk produksi setiap harinya.

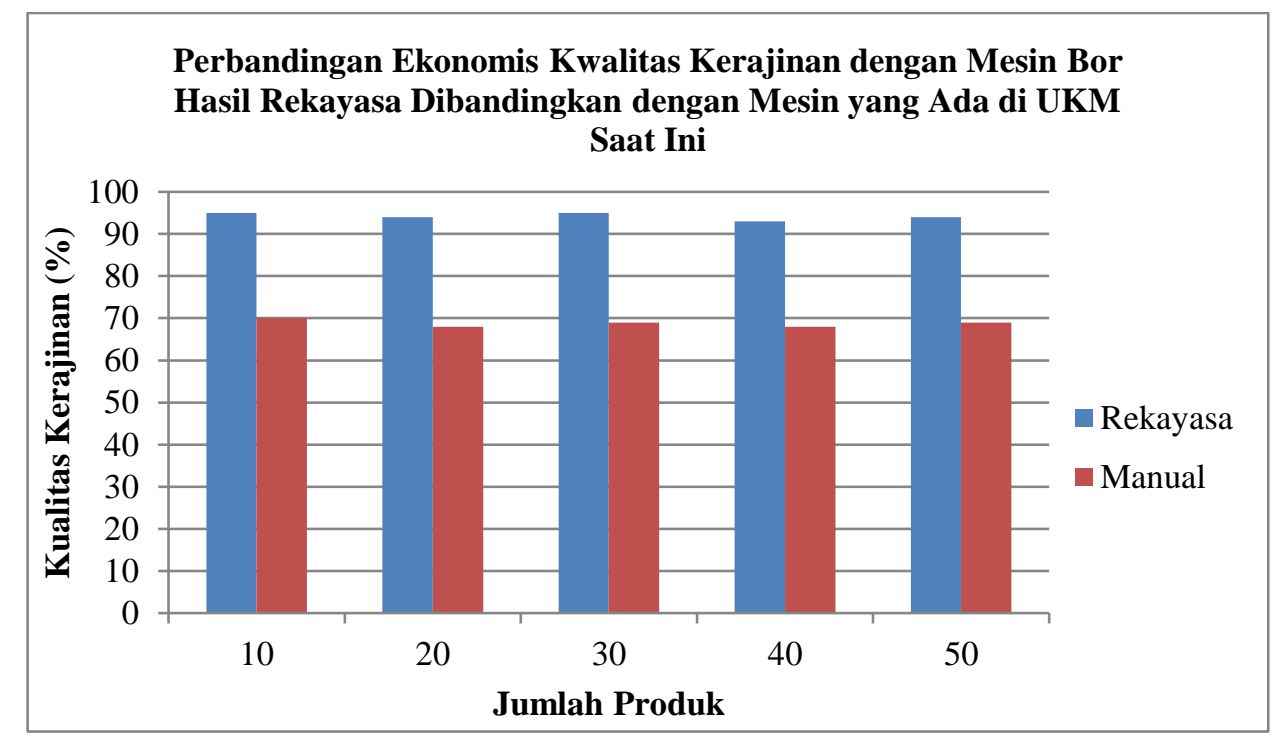

Gambar 6. Grafik Perbandingan Kwalitas Kerajinan dengan

Mesin Bor Hasil Rekayasa dengan Mesin yang Ada di UKM Saat Ini

Grafik 6 yang menunjukkan perbandingan kwalitas pengerjaan terutama kepresisian dan tingkat kehaluan kayu dalam pengeboran dengan mesin bor yang direkayasa dengan mesin bor yang ada di UKM saat ini didapat peningkatan kualitas sebesar $25 \%$ dari waktu pelaksanaan yang sama sehingga mesin bor yang telah diberikan pada UMKM saat ini dapat digunakan untuk produksi setiap harinya. 


\section{KESIMPULAN}

Dari hasil pelaksanaan Program Penerapan Teknologi Tepat Guna kepada Masyarakat dapat diambil kesimpulan sebagai berikut :

a. Mesin Dowel, bisa dikatakan dapat bekerja dengan baik, dalam produksi kerajinan rumah tangga mengalami peningkatan produksi sampai $130 \%$, sedang dalam pengerjaan finishing mengalami peningkatan kwalitas produk sampai $60 \%$, sedangkan biaya operasional mesin mengalami penurunan sebesar $40 \%$.

b. Mesin Gergaji, bisa dikatakan dapat bekerja dengan baik, dalam produksi setiap harinya mengalami peningkatan produksi sampai $30 \%$, sedang dalam pengerjaan finishing mengalami peningkatan kwalitas produk sampai $24 \%$, sedangkan biaya operasional mesin mengalami penurunan sebesar $40 \%$.

c. Mesin Bor, bisa dikatakan dapat bekerja dengan baik, dalam produksi setiap harinya mengalami peningkatan produksi sampai $40 \%$, sedang dalam pengerjaan finishing mengalami peningkatan kwalitas produk sampai $25 \%$, sedangkan biaya operasional mesin mengalami penurunan sebesar $40 \%$.

d. Pengelolan manajemen sudah berjalan dengan baik terbukti sudah tertibnya pembukuan laporan tiap minggu dan tiap bulannya walaupun kadang-kadang lupa untuk memasukkan dalam pembukuan perlu penyempurnaan dalam monitoring didalam pembuatan laporan pembukuan sederhana.

\section{UCAPAN TERIMA KASIH}

a. Kementrian Riset dan Teknologi /Badan Riset dan Inovasi Nasional, kami mengucapkan terima kasih kepada Kementrian Riset dan Teknologi /Badan Riset dan Inovasi Nasional yang telah memberikan dukungan pendanaan pada Program Penerapan Teknologi Tepat Guna kepada Masyarakat yang kami usulkan, sehingga kegiatan yang kami rencanakan dapat berjalan sesuai dengan rencana

b. Kepada Politeknik Pratama Mulia Surakarta, kami mengucapkan terima kasih yang sebesarbesarnya, karena dengan dukungannya secara moril dan fasilitas yang diberikan kepada kami, sehingga dapat melaksanakan kegiatan program Program Penerapan Teknologi Tepat Guna kepada Masyarakat ini.

Kepada kedua Mitra Pengrajin rumah tangga UKM "Krida Mukti" dan UKM "Makaryo" di Dukuh Dawar Desa Manggis Kecamatan Mojosongo Kabupaten Boyolali, kami mengucapkan banyak terima kasih atas kerjasamanya dalam mendukung kegiatan Program Penerapan Teknologi Tepat Guna kepada Masyarakat ini. Atas ide-idenya masukan dari kedua mitra tersebut maka program dapat berjalan dengan baik. Pada kesempatan ini kami juga didukung oleh mitra dari bengkel yang siap akan menggandakan mesin-mesin yang kami rekayasa.

\section{DAFTAR PUSTAKA}

[1] Riyanto, Catur Aris (2013) Strategi kelangsungan usaha industry kerajinan sapu bahan dasar ijuk di desa dawar kelurahan manggis, kecamatan mojosongo kabupaten Boyolali. Other thesis, Universitas Sebelas Maret. [Online].Tersedia: https://eprints.uns.ac.id/id/eprint/15142 [Diakses:22 November 2020].

[2] Pusat Kebijakan Ekonomi Makro. "Strategi Pemberdayaan UMKM Menghadapi Pasar Bebas ASEAN, Badan Kebijakan Fiskal", Wired, 26 September 2014, [Online].Tersedia: https://fiskal.kemenkeu.go.id/kajian/2014/09/26/144720682081326-strategipemberdayaan-umkm-menghadapi-pasar-bebas-asean [Diakses:20 November 2020]. 
[3] Erwinsyah (2013) Analisis pendapatan pengrajin sapu ijuk dan kontribusinya terhadap pendapatan keluarga [Online].Tersedia: https://123dok.com/document/ozld0ly4analisis-pendapatan-pengerajin-sapu-kontribusinya-terhadap-pendapatankeluarga.html [Diakses:10 November 2020]

[4] Wardani Dwi (2012) Analisis industry kecil sapu ijuk di desa medan senembah kecamatan Tanjung morawa kapupaten Deli Serdang, [Online].Tersedia: https://123dok.com/document/yr3w3pvy-analisis-industri-senembah-kecamatantanjung-morawa-kabupaten-serdang.html [Diakses:05 November 2020]

[5] Mardiance (2010) Tinjauan bauran pemasaran usaha kecil menengah kerajinan sapu ijuk asli silungkan kota Sawahlunto, [Online].Tersedia: https://123dok.com/document/qmj5w44q-tinjauan-bauran-pemasaran-usahamenengah-kerajinan-silungkang-sawahlunto.html [Diakses: 12 November 2020] 